\title{
Expression of Kisspeptin (KISS1) and its Receptor GPR54 (KISS1R) in Prostate Cancer
}

\author{
IOANNIS XOXAKOS ${ }^{1,2}$, CONSTANTINA PETRAKI $^{1,3}$, PAUL MSAUEL $^{1}$, ATHANASIOS ARMAKOLAS ${ }^{1}$, \\ ALKIVIADIS GRIGORAKIS ${ }^{2}$, STEFANOS STEFANAKIS ${ }^{2}$ and MICHAEL KOUTSILIERIS ${ }^{1 *}$ \\ ${ }^{1}$ Department of Physiology, Medical School, National and Kapodistrian University of Athens, Athens, Greece; \\ ${ }^{2}$ Department of Urology, General Hospital of Athens "Evaggelismos", Athens, Greece; \\ ${ }^{3}$ Department of Pathology, Metropolitan Hospital, Piraeus, Greece
}

\begin{abstract}
Background/Aim: Prostate cancer (PCa) is the second most commonly diagnosed cancer in men. In contrast to localized disease, metastatic PCa leads to increased mortality. Kisspeptin (KISS1) functions as a metastasis suppressor in various cancers. The aim of this study was to detect the expression of KISS1 and its receptor GPR54 (KISSIR) in prostate cancer. Materials and Methods: The expression of KISS1 and KISSIR was examined in prostate cancer tissue specimens after radical prostatectomy. Results: A higher expression of KISS1 and KISS1R was shown in patients with localized tumors (Stage $\leq I I b)$ compared to patients with advanced (Stage $\geq I I I$ ) tumor. High Gleason score PCa and higher prognostic groups patients showed a lower expression rate of both KISSI and KISSIR. Conclusion: A down-regulation of KISSI-KISSIR system was detected in advanced prostate cancer. KISSIas tumor suppressor might be useful in the future for the diagnosis, risk assessment of prostate cancer progression, as well as a therapeutic target for aggressive tumors.
\end{abstract}

Prostate cancer (PCa) is the second most commonly diagnosed cancer in men, with an estimated 1.1 million diagnoses worldwide in 2012, accounting for $15 \%$ of all cancers diagnosed (1). PSA screening has contributed to an early diagnosis of most prostate cancers (2). Therapeutic options for a localized prostate cancer include surgery and/or radiotherapy. Unfortunately, disease often progresses, as evidenced most often by rising prostate-specific antigen (PSA). Advanced prostate cancer or metastatic disease requires androgen

This article is freely accessible online.

Correspondence to: Michael Koutsilieris, MD, Ph.D., Professor and Chairman, Physiology Laboratory Athens Medical School, NKUA, Mikras Asias 75, 115 27, Goudi, Athens, Greece. Tel: +30 2107462597, Fax: +30 2107462571, e-mail: mkoutsil@med.uoa.gr

Key Words: KISS1, KISS1R, prostate cancer, metastasis suppression. deprivation therapy (3), which however is not curative. Progression to castration-resistant cancer stage often requires additional hormonal or chemotherapy-based interventions (47). Metastasis is the predominant cause of prostate cancer death (8), rather than the original tumor growth.

Over the past two decades, a great variety of molecules have been investigated having a role in suppression of tumor metastasis (9) and have become the target of clinical and basic cancer research.

The expression of kisspeptin (KISS1) and its receptor GPR54 (KISS1R) in prostate cancer has been examined within this study. The goal of our study was to find any existing correlation of KISS1 expression and/or KISS1R with different clinicopathological characteristics of prostate cancer. The findings might be useful in risk assessment of prostate cancer as well as in future development of cancer therapy and prevention of metastasis.

Kisspeptin, KISS1, KISS1 gene, KISS1R, Kiss1r. Several terms that refer to kisspeptin and kisspeptin receptor have been used over the past years. In our study and in accordance to Human Genome Organization Gene Nomenclature Committee (HGNC), KISSI is used to represent the human (primate) kisspeptin gene and Kiss 1 to represent non-human (non-primate) kisspeptin genes. (10). Non-italicized versions of the gene nomenclature are used to refer to the protein products of KISS1 (KISS1 for human and Kiss1 for other species). The full-length peptide products of KISS1/Kiss 1 genes are globally termed KISS1/Kiss1, while their shorter peptides are called kisspeptins (11). Proteolytic fragmentation yields kisspeptins of variable amino acid lengths, i.e. kisspeptin-54, -14, -13, and -10, with the numbers referring to the amino acid length of kisspeptin fragments (10).

Regarding the receptor GPR54 it has been suggested to be named as KISS1R and Kiss1r in human and non-human species, respectively, following again the indications of Human Genome Organization Gene Nomenclature Committee (HGNC) $(10,12)$. However, in our study both names, KISS1R and GPR54, will be valid for the kisspeptin receptor. GPR54 
and Gpr54 refer to the corresponding human and non-human receptor protein, while italicized terms GPR54 and Gpr54 indicate human and non-human genes/mRNAs (12-15).

Kisspeptin (KISS1), receptor GPR54 (KISS1R). While searching for melanoma metastasis-suppressor genes in 1996, Lee and coworkers (16-17) identified a novel cDNA that was only expressed in non-metastatic human melanoma cell lines and named it "KISS-1". They first unveiled the KISS1 gene as a metastasis suppressor for human melanoma. Human KISS1 gene encodes a premature 145 full length amino acid protein $(11,18,19)$, which is called KISS1. KISS1 will be proteolytically cleaved into shorter polypeptides with $54,14,13$, and 10 amino acids known as kisspeptins. The 54-amino acid kisspeptin (Kp-54) was originally called metastin for its ability to inhibit cancer metastasis (18). Each of these Kisspeptin peptides has a common C-terminal amidation site that leads to strong binding with their GPR54 receptor (19). 10 C-terminal amino acids are the minimum fragment length which is necessary to bind and activate the kisspeptin receptor (11). The kisspeptin receptor, known as GPR54 and recently named as KISS1R, is a member of the rhodopsin family with structural similarities to the galanin receptor GPR54 $(10,18)$. The binding of kisspeptin to its receptor GPR54 activates the G-protein $(\mathrm{Gq} / 11)$ and phospholipase C (PLC), which in turn stimulates phosphatidyloinositol (PIP2) turnover into inositol trisphosphate (IP3) and diacylglycerol (DAG). IP3 causes intracellular calcium release, while DAG via activation of protein kinase $\mathrm{C}$ and arachidonic acid release causes stimulation of the mitogen-activated protein kinase (MAPKs), extracellular signal-regulated kinase ERK1 and ERK2 (19-22). Activation of MAPK pathway leads to reduced matrix metalloproteinase-9 (MMP-9) activity. Structural degradation of the extracellular matrix and basement membrane by MMP-9 is thought to be essential in the process of tumor metastasis. As evidenced, the antimetastatic role of kisspeptin and its receptor GPR54, may occur by increasing intracellular calcium release, which promotes cancer cell differentiation and apoptosis, as well as by reducing MMP-9 activity and thereby inhibition of cancer cell migration and invasion (20-22).

KISS1 and GPR54 are both expressed in various tissues, including the placenta, brain, pituitary, testis, ovary, pancreas, intestine, liver, vascular, thyroid (22). Various functions of KISS1 in normal tissues and in cancer have been recognized $(12,23,24)$. In 2003, for the first time, the major neuroendocrinological role of KISS1-GPR54 system signaling was demonstrated, as being gatekeeper for gonadotropin-releasing hormone $(\mathrm{GnRH})$ release in hypothalamus (25). Pituitary release of gonadotropins following by sex-steroid release are absent if there is no functional kisspeptin and GPR54 receptor. This fact results in incapability of humans or mice to undergo puberty (2527). Several subsequent studies have confirmed that kisspeptins act as neuroendocrine peptides that switch on or off the GnRH in hypothalamic-pituitary-gonadal (HPG) axis in humans and mammals (28-36), and are thus required as physiological regulators of sex-steroid release. A recent study investigated the effects of kisspeptin on limbic brain activity and behavior and could provide evidence of a role for kisspeptin in integrating sexual and emotional brain processing with reproduction in humans (37).

In addition to physiological neuroendocrinological activity of kisspeptin, the potential role of KISS1, kisspeptin and its receptor KISS1R in cancer progression and dissemination has gained growing interest in recent years. The effect of KISS1 in tumor suppression and its anti-metastatic function has been documented in many cancers e.g., bladder (38-40), ovarian (41), colorectal (42, 43), pancreas (44), nasopharyngeal (45), pituitary (46), prostate (23), and thyroid $(47,48)$. However hepatocellular carcinoma (49) and breast cancer (50-54), surprisingly, have been promoted by KISS1 expression. Expression of GPR54 and KISS1 in prostate tissue has not been extensively investigated. Some researchers failed to detect KISS-1 expression in cDNA from human prostate, while several other studies $(23,24)$ were able to demonstrate a definite KISS1 staining in benign prostate tissue. Recent studies have shown a down-regulation of KISS1 expression in prostate cancer, as well as a correlation of clinical stage with KISS1 expression and with expression of KISS1R. Prostate cancer cell lines with diminished KISS 1 expression showed increased metastatic ability (23), while on the contrary, cell lines with KISS1 overexpression demonstrated increased chemosensitivity, decreased cell migration and invasion (23). These findings show that the KISS1-KISS1R system has a role in prostate cancer and furthermore loss of KISS1 expression is associated with increased cancer progression and metastasis.

\section{Materials and Methods}

Patients. One hundred eighty-six surgical specimens from patients who underwent radical prostatectomy for localized prostate adenocarcinoma were collected and examined. No other treatment modality, such as hormone therapy or radiotherapy, was used prior to radical prostatectomy. The range of patients' age was 51 to 78 years, while mean patient's age was 65.4 years. All samples were used in accordance with ethical approval of the local committee of the National and Kapodistrian University, Medical School.

Immunohistochemistry. Expression of KISS1 and its receptor GPR54 (KISS1R) was evaluated by immunohistochemistry. KISS1 expression was assessed by cytoplasmic expression, whereas expression of KISS1Receptor was determined by cytoplasmic/ membranous expression. Immunohistochemical staining was performed by the Bond-Max automated Leica Biosystem, Newcastle, UK, using monoclonal Antibody KISS-1 (FL-145) at 
dilution 1:150 as well as polyclonal antibody anti-KISS1R at 1:1,000 dilution. Positive controls were assessed by villous and extravillous trophoblast of the placenta, whereas negative controls were performed by omitting the primary antibody. Histoscore (Hscore) was used to determine the protein immunoreactivity. Semiquantitative assessment of both intensity of staining as well the percentage of positive cells were used to calculate the H-score. Intensity of protein staining was further identified as weak intensity $[1+]$, moderate intensity [2+] or strong intensity [3+], (Figures 1 and 2 ). The percentage of positive cells was determined in every specimen. A final score, ranging from 0 to 300 , was obtained according to the following formula: $1 \times(\%$ of $1+$ cells $)+2 \times(\%$ of $2+$ cells $)+3 \times(\%$ of $3+$ cells $)$. The level of expression could be further classified as 'low' or 'high' according to the median value of the H-score.

Statistical analysis. R statistical computing system (Foundation for Statistical Computing, Vienna, Austria) was used for the statistical analyses. The Kolmogorov-Smirnov test was used to test the assumption of normal distribution in all continuous variables. Normally distributed variables were compared using parametric tests whereas non-normally distributed variables were compared using non-parametric tests. The Spearman correlation coefficient was used to evaluate the associations between continuous and/or categorical ordinal variables. Comparisons of KISS1 or KISS1-R expression between groups were performed using the MannWhitney $U$-test. $p<0.05$ was considered statistically significant.

\section{Results}

In our study we examined the expression of KISS1/Kisspeptin as well as the expression of its receptor GPR54 in prostate tissue, in patients who underwent radical prostatectomy for histologically-proven localized prostate adenocarcinoma. Using the American Joint Committee on Cancer (AJCC) classification, 9 of the 186 patients $(4.8 \%)$ had stage IIa disease, 47/186 (25.3\%) had Stage IIb, 124/186 (66.7\%) had Stage III, and 6/186 (3.2\%) had Stage IV cancer. Most patients $(75.8 \%)$ had a Gleason score of 7 , whereas only $9.1 \%, 6.5 \%$ and $8.6 \%$ had Gleason scores of 6, 8 and 9 respectively. Highgrade prostatic intraepithelial neoplasia (PIN) was observed in the vast majority of patients $(97.8 \%)$. Positive surgical margins were seen in $46.2 \%$ of cases.

The results of our study documented that KISS 1 expression strongly and positively correlated with KISS1-R expression $(\mathrm{r}=0.854 ; p<0.001)$. Median (interquartile range) KISS expression in Stage IIa, IIb, III and IV tumors was 240 $(200-270) \%, 210(106-270) \%, 100(100-152.5) \%$, and 95 (85-100)\% respectively. Median (interquartile range) KISS$\mathrm{R}$ expression in Stage IIa, IIb, III and IV tumors was 205 (120-300)\%, $210(120-240) \%, 105.5$ (95-145)\%, and 90 (80$101) \%$ respectively.

The expression of KISS1 and KISS1-R in relation to patient histological findings as well as their clinical characteristics are shown in Table I and they are further discussed in the discussion section.

\section{Discussion}

Since the initial study by Lee et al. (16) in 1996, which first identified the KISSI gene as a metastasis suppressor for human melanoma, many studies have examined the KISS1 gene, its 145 full-length amino acid product -called KISS1, as well as its shorter amino acid $(54,14,13$, and 10 amino acids) derivatives known as kisspeptins. Kisspeptins exhibit their biological activity and act as endogenous ligands to a $\mathrm{G}$ protein-coupled receptor, called GPR54 and recently named as $\operatorname{KISS} 1 \mathrm{R}(10,18)$.

Among others, a physiological activity of kisspeptin/GPR54 system of great importance is the neuroendocrinological role of kisspeptin in puberty and reproduction, as being gatekeeper for Gonadotropin-Releasing Hormone $(\mathrm{GnRH})$ in hypothalamus, and thus regulating the sex-steroid release.

Additionally, several studies have focused on the potential role of KISS1, kisspeptin and its receptor KISS1R in cancer progression and dissemination $(18,20,21)$. The antimetastatic and/or anti-tumoral roles have been reported in numerous cancers e.g., bladder (38-40), ovarian $(41,42)$, colorectal (43), pancreas (44), nasopharyngeal (45), pituitary (46), prostate (23), and thyroid (47, 48). Interestingly in striking contrast to most cancers, it has been shown that KISS1 and its receptor KISS1R promote hepatocellular carcinoma (49), as well as breast cancer invasion and metastasis (50-54). This dual role of the same molecule, acting as both a promoter and a suppressor of tumor invasion and metastasis is not unique to KISS1 or KISS1R as other molecules such as NFkB, c-Myc, AMP-activated protein kinase (AMPK), transforming growth factor b (TGF-b), SKY, and hyaluronidase have been reported to have dual roles (55-60).

Prostate cancer is the most common malignancy and the second-most common cause of death in human male population (61). Disease progression and metastasis increases dramatically the mortality rate related to prostate cancer. Radical treatments like surgical removal of tumor and/or radiotherapy have a curative intent for localized prostate cancer. However, as disease progresses other therapeutic strategies like Androgen Deprivation Therapy (ADT) are indicated. A variety of agents known as Luteinizing Hormone-Releasing Hormone (LHRH) - also called Gonadotropin-Releasing Hormone (GnRH) - agonists or antagonists are currently used in treating advanced or metastatic prostate cancer. Kisspeptin acts as a positive regulator of the hypothalamus-pituitary-gonadal (HPG) axis by stimulating the GnRH secretion. Studies have shown that administration of potent and long-acting kisspeptin agonists decreased serum testosterone levels by suppressing the HPG axis in rats and humans $(62,63)$. This provides a potential beneficial role of kisspeptin in advanced prostate cancer by altering the androgen status of the disease. 

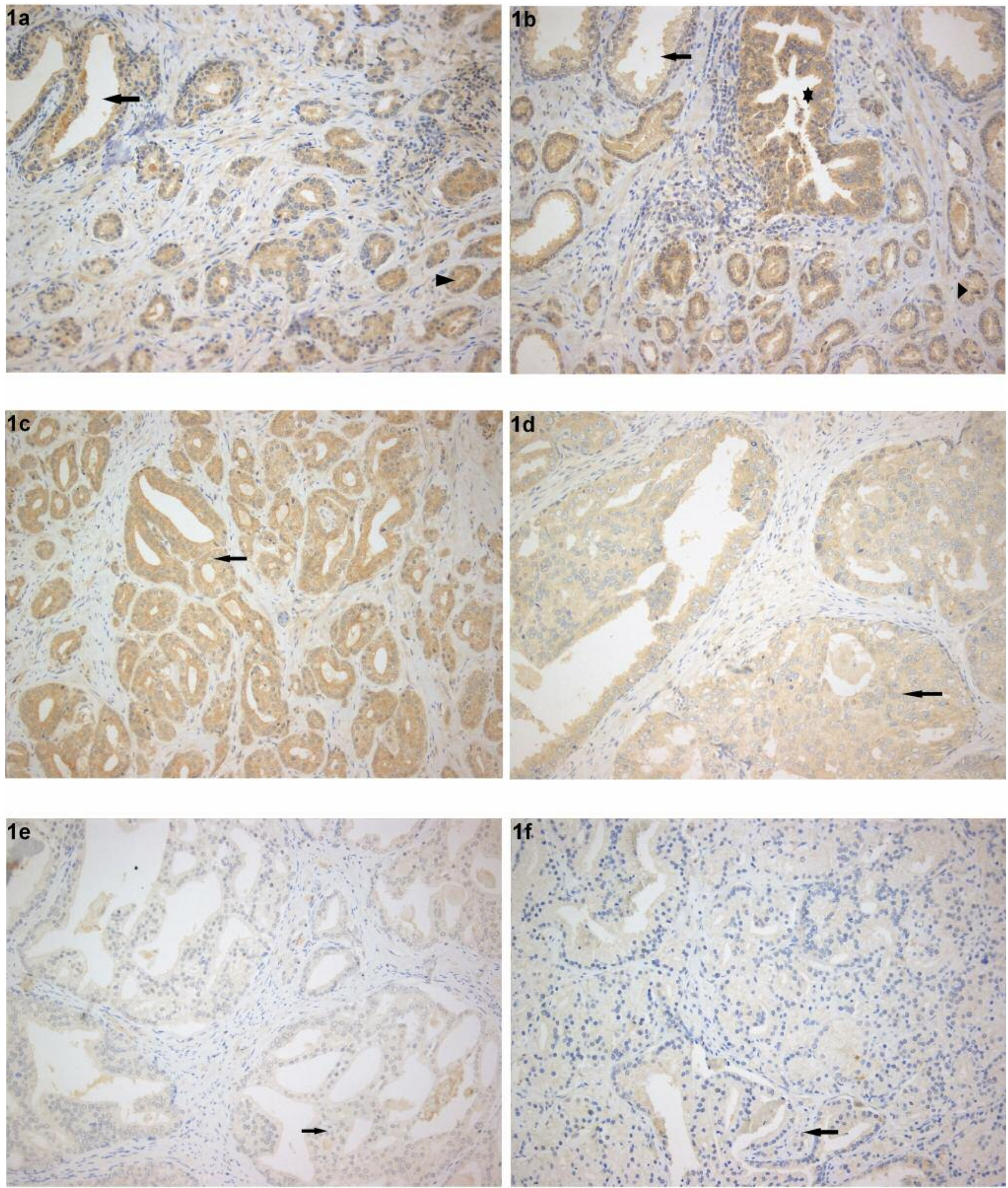

Figure 1. A. Strong Kiss-1 immunohistochemical expression (IE) in normal prostate epithelium (arrow) and Grade Group (GG) 1 prostate cancer (arrowhead). B. Strong Kiss-1 IE in normal prostate epithelium (arrow), high grade PIN (asterisk) and GG 1 prostate cancer (arrowhead). C. Strong Kiss-1 IE in GG 1 prostate cancer (arrow). D. Moderate Kiss-1 IE in GG 4 prostate cancer (arrow). E. Negative and focally weak Kiss-1 IE in GG 4 prostate cancer (arrow), F. Negative and focally weak Kiss-1 IE in GG 5 prostate cancer (arrow). All magnifications $\times 200$. 

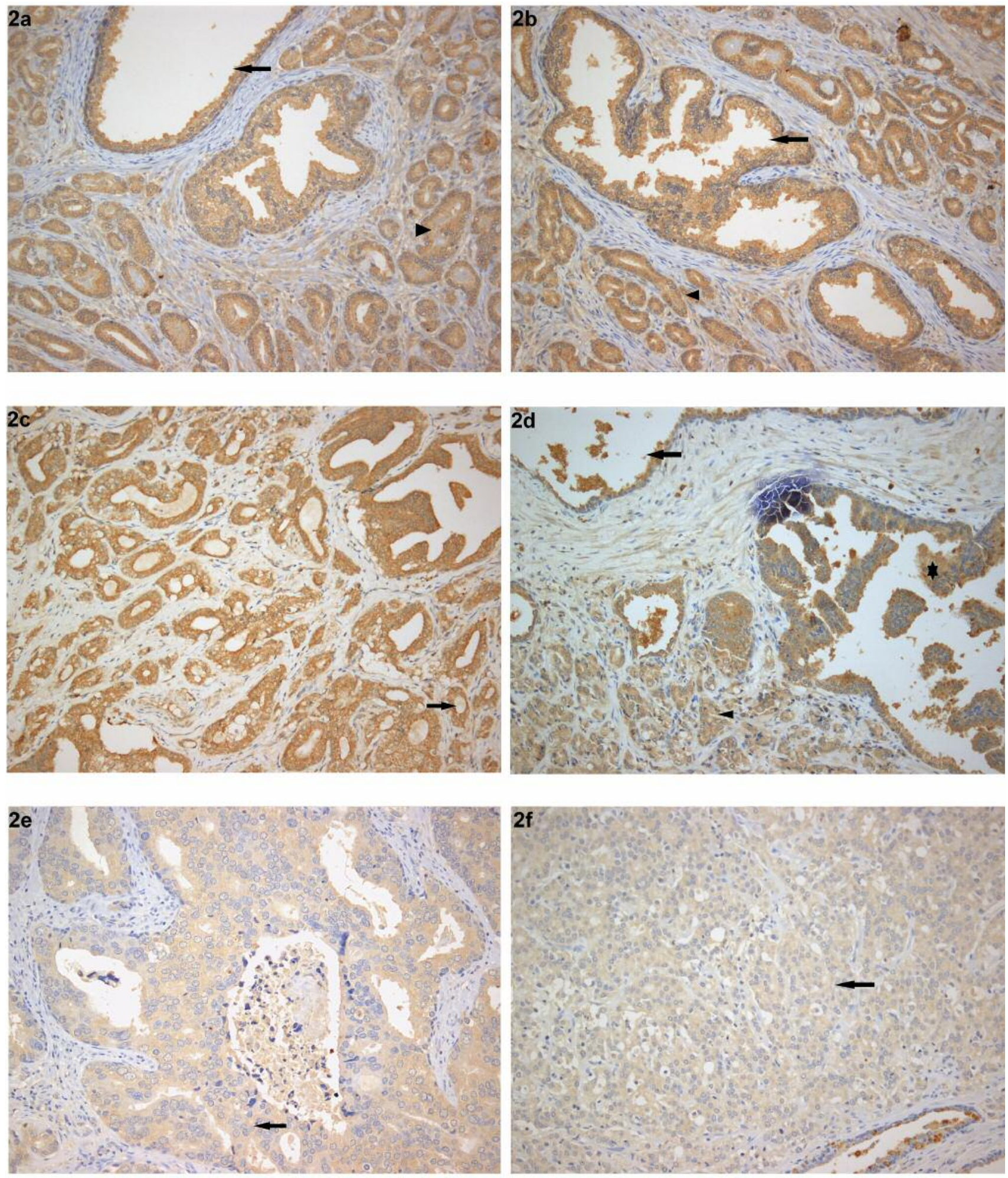

Figure 2. A. Strong Kiss-R immunohistochemical expression (IE) in normal prostate epithelium (arrow) and Grade Group (GG) 1 prostate cancer (arrowhead). B. Strong Kiss-R IE in normal prostate epithelium (arrow) and GG 1 prostate cancer (arrowhead). C. Strong Kiss-R IE in GG 2 prostate cancer (arrow). D. Strong Kiss-R IE in normal prostate epithelium (arrow) and high-grade PIN (asterisk); moderate Kiss-R IE in GG 2 prostate cancer (arrowhead), E. Weak Kiss-R IE in GG 4 prostate cancer (arrow). F. Negative to weak Kiss-R IE in GG 5 prostate cancer (arrow). All magnifications $\times 200$. 
Table I. Correlation of the expression of KISS1 and KISS1R with various clinicopathological characteristics of patients $(N=186)$.

\begin{tabular}{|c|c|c|c|}
\hline Variable & $\mathrm{N}$ & Association with KISS1 expression & Association with KISS1-R expression \\
\hline \multicolumn{4}{|c|}{ Gleason score ${ }^{b}$} \\
\hline 6 & $17(9.1 \%)$ & $\mathrm{r}=-0.413 ; p<0.001^{\mathrm{a}}$ & $\mathrm{r}=-0.470 ; p<0.001^{\mathrm{a}}$ \\
\hline 7 & $141(75.8 \%)$ & & \\
\hline 8 & $12(6.5 \%)$ & & \\
\hline 9 & $16(8.6 \%)$ & & \\
\hline \multicolumn{4}{|c|}{ Prognostic group } \\
\hline $\mathrm{I}$ & $17(9.1 \%)$ & $\mathrm{r}=-0.753 ; p<0.001^{\mathrm{a}}$ & $\mathrm{r}=-0.767 ; p<0.001^{\mathrm{a}}$ \\
\hline II & $68(36.6 \%)$ & & \\
\hline III & $73(39.2 \%)$ & & \\
\hline IV & $12(6.5 \%)$ & & \\
\hline $\mathrm{V}$ & $16(8.6 \%)$ & & \\
\hline \multicolumn{4}{|c|}{ AJCC stage ${ }^{b}$} \\
\hline IIa & $9(4.8 \%)$ & $\mathrm{r}=-0.440 ; p<0.001^{\mathrm{a}}$ & $\mathrm{r}=-0.488 ; p<0.001^{\mathrm{a}}$ \\
\hline $\mathrm{IIb}$ & $47(25.3 \%)$ & & \\
\hline III & $124(66.7 \%)$ & & \\
\hline IV & $6(3.2 \%)$ & & \\
\hline \multicolumn{4}{|l|}{$\mathrm{PINb}$} \\
\hline Absent & $4(2.2 \%)$ & $p=0.555^{\mathrm{b}}$ & $p=0.556^{\mathrm{b}}$ \\
\hline Present & $182(97.8 \%)$ & & \\
\hline \multicolumn{4}{|c|}{ Surgical margins $\mathrm{s}^{\mathrm{b}}$} \\
\hline Negative & $100(53.8 \%)$ & $p=0.276^{\mathrm{b}}$ & $p=0.167^{\mathrm{b}}$ \\
\hline Positive & $86(46.2 \%)$ & & \\
\hline
\end{tabular}

aTested using the Spearman correlation coefficient, ${ }^{b}$ Tested using the Mann-Whitney $U$-test. PIN: Prostatic intraepithelial neoplasia.

Apart from the above indirect function of kisspeptin, the KISS1/KISS1R system seems also to have a direct antimetastatic activity in prostate cancer cells. Wang et al. (23) studied the expression of KISS1 protein in both benign and cancerous prostatic tissue. KISS 1 was strongly expressed in normal prostate as well in prostate with benign hyperplasia (23). On the contrary, a decreased expression has been observed in early-stage tumors, with a progressive loss of expression in late stage and metastatic tumors (23). The loss of KISS 1 expression correlated with both advanced clinical cancer stages and the loss of KISS1R (23). Interestingly, another study from Curtis et al. showed that although kisspeptin is released from human prostate cancer cell lines, plasma kisspeptin levels were not elevated in the examined 92 prostate cancer patients compared to healthy subjects (24). Similarly to the above mentioned data, our present study addressed a significant correlation of KISS1and KISS1R expression with tumor stage and Gleason score of prostate cancer. Among the 186 patients who were treated with radical prostatectomy, the Median (interquartile range) KISS 1 expression was 240 (200-270)\% in patients with Stage IIa, 210 $(106-270) \%$ in stage Ilb patients, $100(100-152.5) \%$ in stage III patients and $95(85-100) \%$ in patients with stage IV prostate cancer. These findings indicate a significantly higher exprssion of KISS1 $(p<0.001)$ in patients with localized tumors (Stage $\leq \mathrm{IIb}$ ) compared to patients with advanced stage
(Stage $\geq \mathrm{III}$ ) of disease. Additionally, the Median (interquartile range) expression of kisspeptin receptor (KISS1R) was 205 $(120-300) \%, 210(120-240) \%, 105.5$ (95-145)\%, and 90 (80$101) \%$ in patients with Stage IIa, IIb, III and IV prostate cancer. Similarly to KISS1, the KISS1R expression is significantly higher $(p<0.001)$ in patients with lower (localized) tumor stage (Stage $\leq \mathrm{IIb}$ ) than in patients with a greater and more advanced disease stage (Stage $\geq \mathrm{III}$ ). Gleason score is another important grading system of prostate cancer and a key factor for treatment decision. In our present study there has been detected a negative correlation of Gleason score with both KISS1 $(r=-0.413, p<0.001)$ and KISS1-R ( $r=-0.470$; $p<0.001)$. Patients with advanced prostate cancer disease with higher Gleason score presented lower expression rate of both KISS 1 and KISS1Receptor. Similar findings with loss of kisspeptin (KISS1) expression ( $\mathrm{r}=-0.753, p<0.001)$, as well as its receptor (KISS1R) expression ( $\mathrm{r}=-0.767, p<0.001)$, have been detected in patients who belong to higher prostate cancer prognostic groups, with a more advanced prostate cancer disease. Prostatic intraepithelial neoplasia (PIN) is considered still as probable precursor lesion of prostate carcinoma. Almost $98 \%$ of patients in our study had a concomitant PIN lesion in addition to prostate carcinoma in the tissue specimen. However, PIN has been detected to have non statistically significant correlation neither with KISS1 expression $(p=0.555)$ nor with KISS1R expression $(p=0.556)$. 
Additionally, other histological findings like positive surgical margins in tissue specimen have also shown no significant correlation with KISS1-or KISS1R expression (all $p>0.1$ ).

The function of kisspeptin as tumor suppressor in prostate cancer has been shown in a study by Wang and coworkers (23). They were able to detect an inhibition of cell migration and invasion, as well as re-sensitization of cells to chemotherapeutics when KISS1 was re-expressed in PC3M cells that lack KISS1 (23). Similar results with inhibition of prostate cancer cell growth and metastasis have been demonstrated in a recent study by activation of eukaryotic translation initiation factor 2a kinase 2 (EIF2AK2) upon kisspeptin and KISS1R stimulation (64).

A very promising clinical use of kisspeptin or kisspeptin mimetics could be developed in the future, based on the previous mentioned finding, that re-expression of KISS1 increases sensitivity to proliferation-targeting agents such as platinum $(65,66)$. These results are similar with the reexpression of KISS1 in head and neck squamous cell carcinoma chemo-resistant cells, restoring chemosensitivity through nuclear factor-kB (NFkB)-associated poly (ADPribose) polymerase- 1 cleavage (66). The role of NFkB in prostate cancer has been investigated, as the NFkB functions in regulating various genes responsible for cell proliferation, epithelial to mesenchymal transition-associated metastasis, and resistance to chemotherapy (67). It is clear that any mechanism or molecule that could inhibit or repress these cellular processes, would promote chemosensitivity and inhibit cancer progression to metastasis.

\section{Conclusion}

In conclusion and in accordance to other studies, this study showed a down-regulation of KISS1 expression and KISS1R in prostate cancer. A decreased expression has been observed in early-stage and low Gleason score prostate tumors, with a progressive loss of expression in late-stage and metastatic tumors. These findings of KISS1/KISS1R system as a tumor suppressor might be useful for the diagnosis, risk assessment of prostate cancer progression, as well as a therapeutic target for aggressive tumors. Additionally, the neuroendocrinological function of kisspeptin in HPG axis, triggering the GnRH secretion, might have a potential therapeutic role in advanced prostate cancer by altering the androgen status of the prostate cancer disease.

However, it is clear that further studies are needed concerning both direct and indirect potential beneficial roles of kisspeptin-KISS1/KISS1R system regarding the prostate cancer risk assessment and treatment.

\section{Conflicts of Interest}

The Authors declare no conflicts of interest.

\section{Authors' Contributions}

I.X: Experimental procedure and writing of the paper; C.P: Experimental procedure and writing of the paper; P.M: statistical analysis of the paper; A.A: designing of the study and editing of the paper; A.G: editing the paper; S.S: editing the paper; M.K: designing the study and editing the paper.

\section{References}

1 European Urology Association (EAU), Prostate Cancer Guidelines 2019. Available at: https://uroweb.org/guideline/ prostate-cancer/

2 Cooperberg MR, Lubeck DP, Meng MV, Mehta SS and Carroll PR: The changing face of low-risk prostate cancer: trends in clinical presentation and primary management. J Clin Oncol 22(11): 2141-2149, 2004. PMID: 15169800. DOI: 10.1200/ JCO.2004.10.062

3 National Comprehensive Cancer Network. Clinical Practice Guidelines in Oncology. Prostate Cancer. Version 2. NCCN Guidelines 2013. Available at: https://www.nccn.org/professionals/ physician_gls/default.aspx

4 De Bono JS, Oudard S, Ozguroglu M, Hansen S, Machiels JP, Kocak I, Gravis G, Bodrogi I, Mackenzie MJ, Shen L, Roessner M, Gupta S and Sartor AO: Prednisone plus cabazitaxel or mitoxantrone for metastatic castration-resistant prostate cancer progressing after docetaxel treatment: arandomised open-label trial. Lancet 376(9747): 1147-1154, 2010. PMID: 20888992. DOI: 10.1016/S0140-6736(10)61389-X

5 Chen X, Liu Y, Wu J, Huang H, Du Z, Zhang K, Zhou D, Hung $\mathrm{K}$, Goodin $\mathrm{S}$ and Zheng $\mathrm{X}$ : Mechanistic study of inhibitory effects of atorvastatin and docetaxel in combination on prostate cancer. Cancer Genomics Proteomics 13(2): 151-160, 2016. PMID: 26912805.

6 De Bono JS, Logothetis CJ, Molina A, Fizazi K, North S, Chu L, Chi KN, Jones RJ, Goodman OB Jr, Saad F, Staffurth JN, Mainwaring P, Harland S, Flaig TW, Hutson TE, Cheng T, Patterson H, Hainsworth JD, Ryan CJ, Sternberg CN, Ellard SL, Fléchon A, Saleh M, Scholz M, Efstathiou E, Zivi A, Bianchini D, Loriot Y, Chieffo N, Kheoh T, Haqq CM and Scher HI: Abiraterone and increased survival in metastatic prostate cancer. N Engl J Med 364(21): 1995-2005, 2011. PMID: 21612468. DOI: $10.1056 /$ NEJMoa1014618

7 Scher HI, Fizazi K, Saad F, Taplin ME, Sternberg CN, Miller K, de Wit R, Mulders P, Chi KN, Shore ND, Armstrong AJ, Flaig TW, Fléchon A, Mainwaring P, Fleming M, Hainsworth JD, Hirmand M, Selby B, Seely L and de Bono JS: Increased survival with enzalutamide in prostate cancer after chemotherapy. N Engl J Med 367(13): 1187-1197, 2012. PMID: 22894553. DOI: 10.1056/NEJMoa1207506

8 Jemal A, Siegel R, Xu J and Ward E: Cancer statistics, 2010. CA Cancer J Clin 60(5): 277-300, 2010. PMID: 20610543. DOI: $10.3322 /$ caac 20073

9 Stafford LJ, Vaidya KS and Welch DR: Metastasis suppressors genes in cancer. Int J Biochem Cell Biol 40(5): 874-891, 2008. PMID: 18280770. DOI: 10.1016/j.biocel.2007.12.016

10 Gottsch ML, Clifton DK and Steiner RA: From KISS1 to kisspeptins: an historical perspective and suggested nomenclature. Peptides 30(1): 4-9, 2009. DOI: 10.1016/j.peptides.2008.06.016 
11 Kotani M, Detheux M, Vandenbogaerde A, Communi D, Vanderwinden JM, Le Poul E, Brezillon S, Tyldesley R, SuarezHuerta N, Vandeput F, Blanpain C, Schiffmann SN, Vassart G and Parmentier M: The metastasis suppressor gene KiSS-1 encodes kisspeptins, the natural ligands of the orphan G proteincoupled receptor GPR54. J Biol Chem 276(37): 34631-34636, 2001. PMID: 11457843 . DOI: $10.1074 /$ jbc.M104847200

12 Pinilla L, Aguilar E, Dieguez C, Millar RP and Tena-Sempere M: Kisspeptins and reproduction: physiological roles and regulatory mechanisms. Physiol Rev 92(3): 1235-1316, 2012. PMID: 22811428. DOI: 10.1152/physrev.00037.2010

13 Papaoiconomou E, Msaouel P, Makri A, Diamanti-Kandarakis E and Koutsilieris M: The role of kisspeptin/GPR54 in the reproductive system. In Vivo 25(3): 343-354, 2011. PMID: 21576407.

14 Makri A, Msaouel P, Petraki C, Milingos D, Protopapas A, Liapi A, Antsaklis A, Magkou C and Koutsilieris M: KISS1/KISS1R expression in eutopic and ectopic endometrium of women suffering from endometriosis. In Vivo 26(1): 119-127, 2012. PMID: 22210725.

15 Lyubimov Y, Engstrom M, Wurster S, Savola JM, Korpi ER and Panula P: Human kisspeptins activate neuropeptide FF2 receptor. Neuroscience 170: 117-122, 2010. PMID: 20600636. DOI: 10.1016/j.neuroscience.2010.06.058

16 Lee JH, Miele ME, Hicks DJ, Phillips KK, Trent JM, Weissman BE and Welch DR: KiSS1, a novel melanoma human malignant metastasis-suppressor gene. J Natl Cancer Inst 88(23): 17311737, 1996. PMID: 8944003. DOI: 10.1093/jnci/88.23.1731

17 Lee JH and Welch DR: Suppression of metastasis in human breast carcinoma MDA-MB-435 cells after transfection with the metastasis suppressor gene, KiSS-1. Cancer Res 579(12): 23842387, 1997. PMID: 9192814.

18 Guzman S, Brackstone M, Radovick S, Babwah AV and Bhattacharya MM: KISS1/KISS1R in Cancer: Friend or Foe? Front Endocrinol (Lausanne) 9(3): 437, 2018. PMID: 30123188. DOI: $10.3389 /$ fendo. 2018.00437

19 Ohtaki T, Shintani Y, Honda S, Matsumoto H, Hori A, Kanehashi K, Terao Y, Kumano S, Takatsu Y, Masuda Y, Ishibashi Y, Watanabe T, Asada M, Yamada T, Suenaga M, Kitada C, Usuki S, Kurokawa T, Onda H, Nishimura $\mathrm{O}$ and Fujino M: Metastasis suppressor gene KiSS-1 encodes peptide ligand of a G-protein-coupled receptor. Nature 411(6837): 613617, 2001. PMID: 11385580. DOI: 10.1038/35079135

20 Makri A, Pissimissis N, Lembessis P, Polychronakos C and Koutsilieris M: The kisspeptin (KiSS-1)/GPR54 system in cancer biology. Cancer Treat Rev 34(8): 682-692, 2008. PMID: 18583061. DOI: 10.1016/j.ctrv.2008.05.007

21 Muir AI, Chamberlain L, Elshourbagy NA, Michalovich D, Moore DJ, Calamari A, Szekeres PG, Sarau HM, Chambers JK, Murdock P, Steplewski K, Shabon U, Miller JE, Middleton SE, Darker JG, Larminie CG, Wilson S, Bergsma DJ, Emson P, Faull R, Philpott KL and Harrison DC: AXOR12, a novel human G protein-coupled receptor, activated by the peptide KiSS-1. J Biol Chem 276(31): 28969-28975, 2001. PMID: 11387329. DOI: $10.1074 /$ jbc.M102743200

22 Stathaki M, Stamatiou E, Magioris G, Simantiris S, Syrigos N, Dourakis S, Koutsilieris $\mathrm{M}$ and Armakolas A: The role of kisspeptin system in cancer biology. Crit Rev Oncol Hematol 142: 130-140, 2019. PMID: 31401420. DOI: 10.1016/ j.critrevonc.2019.07.015

23 Wang H, Jones J, Turner T, He QP, Hardy S, Grizzle WE, Welch DR and Yates C: Clinical and biological significance of KISS1 expression in prostate cancer. Am J Pathol 180(3): 1170-1178, 2012. PMID: 22226740. DOI: 10.1016/j.ajpath.2011.11.020

24 Curtis AE, Murphy K, Chaudhuri O, Ramachandran R, Young A, Waxman J, Nijher G, Bewick G, Ghatei M, Bloom S and Dhillo W: Kisspeptin is released from human prostate cancer cell lines, but plasma kisspeptin is not elevated in patients with prostate cancer. Oncol Rep 23(6): 1729-1734, 2010. PMID: 20428832. DOI: 10.3892 /or_00000818

25 Seminara SB, Messager S, Chatzidaki EE, Thresher RR, Acierno JS, Shagoury IK, Bo-Abbas Y, Kuohung W, Schwinof KM, Hendick AG Zahn D, Dixon J, Kaiser UB, Slaugenhaupt SA, Gusella JF, O'Rahilly S, Carlton MB, Crowley WF Jr., Aparicio SA and Colledge WH: The GPR54 gene as a regulator of puberty. N Engl J Med 349: 1614-1627, 2003. PMID: 22226740. DOI: $10.1016 /$ j.ajpath.2011.11.020

26 Ciaramella V, Della Corte CM, Ciardiello F and Morgillo F: Kisspeptin and cancer: Molecular interaction, biological functions, and future perspectives. Front Endocrinol (Lausanne) 9: 115, 2018. PMID: 29662466. DOI: 10.3389/fendo.2018.00115

27 De Roux N, Genin E, Carel JC, Matsuda F, Chaussain JL and Milgrom E: Hypogonadotropichypogonadism due to loss of function of the KiSS1-derived peptide receptor GPR54. Proc Natl Acad Sci USA 100: 10972-10976, 2003. PMID: 12944565. DOI: $10.1073 /$ pnas.1834399100

28 Trevisan CM, Montagna E, de Oliveira R, Christofolini DM, Barbosa CP, Crandall KA and Bianco B. Kisspeptin/GPR54 System: What do we know about its role in human reproduction? Cell Physiol Biochem 49(4): 1259-1276, 2018. PMID: 30205368. DOI: $10.1159 / 000493406$

29 Plant TM: The neurobiological mechanism underlying hypothalamic GnRH pulse generation: the role of kisspeptin neurons in the arcuate nucleus. F1000 Res 8 (F1000 Faculty Rev): 982, 2019. PMID: 31297186. DOI: 10.12688/f1000 research.18356.1

30 Seminara SB: Metastin and its G protein-coupled receptor, GPR54: critical pathway modulating GnRH secretion. Front Neuroendocrinol 26(3-4): 131-138, 2005. PMID: 16309735. DOI: $10.1016 /$ j.yfrne.2005.10.001

31 Dhillo WS, Chaudhri OB, Patterson M, Thompson EL, Murphy KG, Badman MK, McGowan BM, Amber V, Patel S, Ghatei MA and Bloom SR: Kisspeptin-54 stimulates the hypothalamic-pituitary gonadal axis in human males. J Clin Endocrinol Metab 90(12): 6609-6615, 2005. PMID: 16174713. DOI: $10.1210 /$ jc. $2005-1468$

32 Patterson M, Murphy KG, Thompson EL, Patel S, Ghatei MA and Bloom SR: Administration of kisspeptin-54 into discrete regions of the hypothalamus potently increases plasma luteinising hormone and testosterone in male adult rats. $\mathbf{J}$ Neuroendocrinol 18(5): 349-354, 2006. PMID: 16629833. DOI: 10.1111/j.1365-2826.2006.01420.x

33 Nazian SJ: Role of metastin in the release of gonadotropinreleasing hormone from the hypothalamus of the male rat. J Androl 27(3): 444-449, 2006. PMID: 16339453. DOI: 10.2164 /jandrol.05144

34 Castellano JM, Navarro VM, Fernandez-Fernandez R, Castano JP, Malagon MM, Aguilar E, Dieguez C, Magni P, Pinilla L and Tena-Sempere M: Ontogeny and mechanisms of action for the stimulatory effect of kisspeptin on gonadotropin-releasing hormone system of the rat. Mol Cell Endocrinol 257-258: 7583, 2006. PMID: 16930819. DOI: 10.1016/j.mce.2006.07.002 
35 Tng EL: Kisspeptinsignalling and its roles in humans. Singapore Med J 56(12): 649-656, 2015. PMID: 26702158. DOI: 10.11622/ smedj.2015183

36 Chianese R, Colledge WH, Fasano S and Meccariello S: Editorial: The multiple facets of kisspeptin activity in biological systems. Front Endocrinol (Lausanne) 9: 727, 2018. PMID: 30559719. DOI: $10.3389 /$ fendo.2018.00727

37 Comninos AN, Wall MB, Demetriou L, Shah AJ, Clarke SA, Narayanaswamy S, Nesbitt A, Izzi-Engbeaya C, Prague JK, Abbara A, Ratnasabapathy R, Salem V, Nijher GM, Jayasena CN, Tanner M, Bassett P, Mehta A, Rabiner EA, Hönigsperger C, Silva MR, Brandtzaeg OK, Lundanes E, Wilson SR, Brown RC, Thomas SA, Bloom SR and Dhillo WS: Kisspeptin modulates sexual and emotional brain processing in humans. $\mathrm{J}$ Clin Invest 127(2): 709-719, 2017. PMID: 28112678. DOI: 10.1172/JCI89519

38 Sanchez-Carbayo M, Capodieci P and Cordon-Cardo C: Tumor suppressor role of KiSS-1 in bladder cancer: loss of KiSS-1 expression is associated with bladder cancer progression and clinical outcome. Am J Pathol 162(2): 609-617, 2003. PMID: 12547718. DOI: $10.1016 /$ S0002-9440(10)63854-0

39 Cebrian V, Fierro M, Orenes-Pinero E, Grau L, Moya P, Ecke T, Alvarez M, Gil M, Algaba F, Bellmunt J, Cordon-Cardo C, Catto J, López-Beltrán A and Sánchez-Carbayo M: KISS1 methylation and expression as tumor stratification biomarkers and clinical outcome prognosticators for bladder cancer patients. Am J Pathol 179(2): 540-546, 2011. PMID: 21683672. DOI: 10.1016/ j.ajpath.2011.05.009

40 Takeda T, Kikuchi E, Mikami S, Suzuki E, Matsumoto K, Miyajima A, Okada Y and Oya M: Prognostic role of KiSS-1 and possibility of therapeutic modality of metastin, the final peptide of the KiSS-1 gene, in urothelial carcinoma. Mol Cancer Ther 11(4): 853-863, 2012. PMID: 22367780. DOI: 10.1158/1535-7163.MCT-11-0521

41 Prentice LM, Klausen C, Kalloger S, Kobel M, McKinney S, Santos JL, Kenney C, Mehl E, Gilks CB, Leung P, Swenerton $\mathrm{K}$, Huntsman DG and Aparicio SA: Kisspeptin and GPR54 immunoreactivity in a cohort of 518 patients defines favourable prognosis and clear cell subtype in ovarian carcinoma. BMC Med 5: 33, 2007. PMID: 18005407. DOI: 10.1186/1741-70155-33

42 Jiang Y, Berk M, Singh LS, Tan H, Yin L, Powell CT and Xu Y: KiSS1 suppresses metastasis in human ovarian cancer via inhibition of protein kinase C alpha. Clin Exp Metastasis 22(5): 369-376, 2005. PMID: 16283480. DOI: 10.1007/s10585-005-8186-4

$43 \mathrm{Kim}$ JN, Kim TH, Yoon JH and Cho SG: Kisspeptin inhibits colorectal cancer cell invasiveness by activating PKR and PP2A. Anticancer Res 38(10): 5791-5798, 2018. PMID: 30275201. DOI: 10.21873 /anticanres.12918

44 Masui T, Doi R,Mori T, Toyoda E, Koizumi M, Kami K, Ito D, Peiper SC, Broach JR, Oishi S, Niida A, Fujii N and Imamura M: Metastin and its variant forms suppress migration of pancreatic cancer cells. Biochem Biophys Res Commun 315(1): 85-92, 2004. PMID: 15013429. DOI: 10.1016/j.bbrc.2004.01.021

45 Wang GM, Liu JF, Zhang L, Sun Q, Zhou Y, Xu HB, Zhang YJ, Cai F, Cheng ZN, Xiang P and Jiang H: Inhibition of KiSS-1 on metastasis of nasopharyngeal carcinoma implant tumor in nude mice. Am J Transl Res 11(2): 904-910, 2019. PMID: 30899390.

46 Martinez-Fuentes AJ, Molina M, Vazquez-Martinez R, Gahete MD, Jimenez-Reina L, Moreno-Fernandez J, Benito-López P,
Quintero A, de la Riva A, Diéguez C, Soto A, Leal-Cerro A, Resmini E, Webb SM, Zatelli MC, degli Uberti EC, Malagón MM, Luque RM and Castaño JP: Expression of functional KISS1 and KISS1R system is altered in human pituitary adenomas: evidence for apoptotic action of kisspeptin-10. Eur J Endocrinol 164(3): 355-362, 2011. PMID: 21169415. DOI: 10.1530/EJE-10-0905

47 Ringel MD, Hardy E, Bernet VJ, Burch HB, Schuppert F, Burman KD and Saji M: Metastin receptor is overexpressed in papillary thyroid cancer and activates MAP kinase in thyroid cancer cells. J Clin Endocrinol Metab 87: 2399, 2002. PMID: 11994395. DOI 10.1210/jcem.87.5.8626

48 Savvidis C, Papaoiconomou E, Petraki C, Msaouel P and Koutsilieris M: The role of KISS1/KISS1R system in tumor growth and invasion of differentiated thyroid cancer. Anticancer Res 35(2): 819-826, 2015. PMID: 25667462.

49 Ikeguchi M, Hirooka Y and Kaibara N: Quantitative reverse transcriptase polymerase chain reaction analysis for KiSS-1 and orphan G-protein coupled receptor (hOT7T175) gene expression in hepatocellular carcinoma. J Cancer Res Clinic Oncol 129(9): 531-535, 2003. PMID: 12898236. DOI: 10.1007/s00432-0030469-z

50 Marot D, Bieche I, Aumas C, Esselin S, Bouquet C, Vacher S, Lazennec G, Perricaudet M, Kuttenn F, Lidereau R and de Roux N: High tumoral levels of Kiss 1 and G-protein-coupled receptor 54 expression are correlated with poor prognosis of estrogen receptor-positive breast tumors. Endocr Relat Cancer 14(3): 691-702, 2007. PMID: 17914099. DOI: 10.1677/ERC07-0012

51 Cvetkovic D, Dragan M, Leith SJ, Mir ZM, Leong HS, Pampillo M, Lewis JD, Babwah AV and Bhattacharya M: KISS1R induces invasiveness of estrogen receptor-negative human mammary epithelial and breast cancer cells. Endocrinology 154(6): 1999-2014, 2013. PMID: 23525242. DOI: $10.1210 / \mathrm{en} .2012-2164$

52 Blake A, Dragan M, Tirona RG, Hardy DB, Brackstone M, Tuck $\mathrm{AB}, \mathrm{Babwah} \mathrm{AV}$ and Bhattacharya M: G protein-coupled KISS 1 receptor is overexpressed in triple negative breast cancer and promotes drug resistance. Sci Rep 7: 46525, 2017. PMID: 28422142. DOI: $10.1038 /$ srep46525

53 Goertzen CG, Dragan M, Turley E, Babwah AV and Bhattacharya M: KISS1R signaling promotes invadopodia formation in human breast cancer cell via beta-arrestin2/ERK. Cell Signal 28(3): 165-176, 2016. PMID: 26721186. DOI: 10.1016/j.cellsig.2015.12.010

54 Papaoiconomou E, Lymperi M, Petraki C, Philippou A, Msaouel P, Michalopoulou F, Kafiri G, Vassilakos G, Zografos G and Koutsilieris M: Kiss-1/GPR54 protein expression in breast cancer. Anticancer Res 34(3): 1401-1407, 2014. PMID: 24596387.

55 Perkins ND: NF-kappaB: tumor promoter or suppressor? Trends Cell Biol 14(2): 64-69, 2004. PMID: 15102437. DOI: $10.1016 /$ j.tcb.2003.12.004

56 Uribesalgo I, Benitah SA and Di Croce L: From oncogene to tumor suppressor: the dual role of Myc in leukemia. Cell Cycle 11(9): 1757-1764, 2012. PMID: 22510570. DOI: 10.4161/cc.19883

57 Zadra G, Batista JL and Loda M: Dissecting the dual role of AMPK in cancer: from experimental to human studies. Mol Cancer Res 13(7): 1059-1072, 2015. PMID: 25956158. DOI: 10.1158/1541-7786.MCR-15-0068 
58 Bachman KE and Park BH: Duel nature of TGF-beta signaling: tumor suppressor $v s$. tumor promoter. Curr Opin Oncol 17(1): 49-54, 2005. PMID: 15608513. DOI: 10.1097/01.cco.000 0143682.45316.ae

59 Krisenko MO and Geahlen RL: Calling in SYK: SYK's dual role as a tumor promoter and tumor suppressor in cancer. Biochim Biophys Acta 1853(1): 254-263, 2015. PMID: 25447675. DOI: 10.1016/j.bbamcr.2014.10.022

60 Lokeshwar VB, Cerwinka WH, Isoyama T and Lokeshwar BL: HYAL1 hyaluronidase in prostate cancer: a tumor promoter and suppressor. Cancer Res 65(17): 7782-7789, 2005. PMID: 16140946. DOI: 10.1158/0008-5472.CAN-05-1022

61 Siegel RL, Miller KD and Jemal A: Cancer statistics, 2016. CA Cancer J Clin 66(1): 7-30, 2016. PMID: 26742998. DOI: $10.3322 /$ caac. 21332

62 Matsui H, Masaki T, Akinaga Y, Kiba A, Takatsu Y, Nakata D, Tanaka A, Ban J, Matsumoto S, Kumano S, Suzuki A, Ikeda Y, Yamaguchi $M$, Watanabe $T$, Ohtaki $\mathrm{T}$ and Kusaka $\mathrm{M}$ : Pharmacologic profiles of investigational kisspeptin/metastin analogues, TAK-448 and TAK-683, in adult male rats in comparison to the GnRH analogue leuprolide. Eur J Pharmacol 735: 77-85, 2014. PMID: 24747751. DOI: 10.1016/j.ejphar.2014.03.058

63 Mac Lean DB, Matsui H, Suri A, Neuwirth R and Colombel M: Sustained exposure to the investigational Kisspeptin analog, TAK-448, down-regulates testosterone into the castration range in healthy males and in patients with prostate cancer: results from two phase 1 studies. J Clin Endocrinol Metab 99(8): E1445-1453, 2014. PMID: 24762108. DOI: 10.1210/jc.20134236
$64 \mathrm{Kim}$ TH and Cho SG: Kisspeptin inhibits cancer growth and metastasis via activation of EIF2AK2. Mol Med Rep 16(5): 7585-7590, 2017. PMID: 28944853. DOI: 10.3892/ mmr.2017.7578

65 Beck BH and Welch DR: The KISS1 metastasis suppressor: a good night kiss for disseminated cancer cells. Eur J Cancer 46(7): 1283-1289, 2010. PMID: 20303258. DOI: 10.1016/ j.ejca.2010.02.023

66 Jiffar T, Yilmaz T, Lee J, Hanna E, El-Naggar A, Yu D, Myers JN and Kupferman ME: KiSS1 mediates platinum sensitivity and metastasis suppression in head and neck squamous cell carcinoma. Oncogene 30(28): 3163-3173, 2011. PMID: 21383688. DOI: $10.1038 /$ onc 2011.39

67 Paule B, Terry S, Kheuang L, Soyeux P, Vacherot F and de la Taille A: The NF-kappaB/IL-6 pathway in metastatic androgenindependent prostate cancer: new therapeutic approaches? World J Urol 25: 477-489, 2007. PMID: 17541600. DOI: 10.1007/ s00345-007-0175-6
Received November 4, 2019

Revised December 13, 2019

Accepted December 16, 2019 